\title{
Development of Thermophilic Tailor-Made Enzyme Mixtures for the Bioconversion of Agricultural and Forest Residues
}

\author{
Anthi Karnaouri ${ }^{1}$, Leonidas Matsakas ${ }^{1}$, Evangelos Topakas ${ }^{1,2}$, Ulrika Rova ${ }^{1}$ and \\ Paul Christakopoulos ${ }^{1 *}$
}

${ }^{1}$ Biochemical Process Engineering, Chemical Engineering, Department of Civil, Environmental and Natural Resources Engineering, Luleå University of Technology, Luleå, Sweden, ${ }^{2}$ Biotechnology Laboratory, Department of Synthesis and Development of Industrial Processes, School of Chemical Engineering, National Technical University of Athens, Athens, Greece

\section{OPEN ACCESS}

Edited by:

Vijai Kumar Gupta, NUI Galway, Ireland

Reviewed by:

Seung Gu Shin,

Pohang University of Science and Technology, South Korea Jean-Guy Berrin, National Institute of Agricultural Research, France

*Correspondence:

Paul Christakopoulos paul.christakopoulos@ltu.se

Specialty section:

This article was submitted to Microbiotechnology, Ecotoxicology

and Bioremediation,

a section of the journal

Frontiers in Microbiology

Received: 16 December 2015 Accepted: 01 February 2016 Published: 16 February 2016

Citation:

Karnaouri A, Matsakas L, Topakas E, Rova U and Christakopoulos P (2016)

Development of Thermophilic

Tailor-Made Enzyme Mixtures for the Bioconversion of Agricultural and

Forest Residues.

Front. Microbiol. 7:177.

doi: 10.3389/fmicb.2016.00177
Even though the main components of all lignocellulosic feedstocks include cellulose, hemicellulose, as well as the protective lignin matrix, there are some differences in structure, such as in hardwoods and softwoods, which may influence the degradability of the materials. Under this view, various types of biomass might require a minimal set of enzymes that has to be tailor-made. Partially defined complex mixtures that are currently commercially used are not adapted to efficiently degrade different materials, so novel enzyme mixtures have to be customized. Development of these cocktails requires better knowledge about the specific activities involved, in order to optimize hydrolysis. The role of filamentous fungus Myceliophthora thermophila and its complete enzymatic repertoire for the bioconversion of complex carbohydrates has been widely proven. In this study, four core cellulases (MtCBH7, MtCBH6, MtEG5, and MtEG7), in the presence of other four "accessory" enzymes (mannanase, lytic polyssacharide monooxygenase MtGH61, xylanase, MtFae1a) and $\beta$-glucosidase MtBGL3, were tested as a nine-component cocktail against one model substrate (phosphoric acid swollen cellulose) and four hydrothermally pretreated natural substrates (wheat straw as an agricultural waste, birch, and spruce biomass, as forest residues). Synergistic interactions among different enzymes were determined using a suitable design of experiments methodology. The results suggest that for the hydrolysis of the pure substrate (PASC), high proportions of MtEG7 are needed for efficient yields. $M t C B H 7$ and $M t E G 7$ are enzymes of major importance during the hydrolysis of pretreated wheat straw, while $\mathrm{MtCBH7}$ plays a crucial role in case of spruce. Cellobiohydrolases $\mathrm{MtCBH} 6$ and $\mathrm{MtCBH}$ act in combination and are key enzymes for the hydrolysis of the hardwood (birch). Optimum combinations were predicted from suitable statistical models which were able to further increase hydrolysis yields, suggesting that tailor-made enzyme mixtures targeted toward a particular residual biomass can help maximize hydrolysis yields. The present work demonstrates the change from "one cocktail for all" to "tailor-made cocktails" that are needed for the efficient saccharification of targeted feed stocks prior to the production of biobased products through the biorefinery concept.

Keywords: enzyme mixture, thermostable enzymes, Myceliophthora thermophila, hydrolysis, experimental design 


\section{INTRODUCTION}

Cellulose, the most abundant polysaccharide on Earth, is a remarkable pure organic polymeric component of plant material, consisting solely of 1,4-linked $\beta$-D-glucopyranose units held together in a giant straight chain molecule. Wood represents a composite material with cellulose as a major part combined in excellent form with lignin and hemicelluloses, creating a unique high-strength and durable material, and recently came again into focus as a renewable energy resource. In nature, a variety of microorganisms are known for producing a set of enzymes capable of degrading this insoluble polymer to soluble sugars, primarily cellobiose, and glucose. Enzymes involved in these processes are called cellulases and are consisting of at least three classes of enzymes, namely, endogluganases (EG), cellobiohydrolases $(\mathrm{CBH})$, and $\beta$-glucosidases (BG). Apart from cellulases, an enzymatic system capable of oxidative cleavage is required for the cellulose degradation, consisting mainly of lytic polysaccharide monooxygenases (LPMOs) that increases the efficiency of cellulases (Horn et al., 2012). Cellulases can be used in the variety of applications within food, vine, animal feed, textile, and pulp and paper industry (Bhat, 2000). The application and interest in cellulases has particularly increased in recent years with the utilization of these enzymes, together with enzymes hydrolyzing hemicellulose (Rosgaard et al., 2007; Zhang et al., 2010) in the production of bioethanol from lignocellulose (Sun and Cheng, 2002). It has been predicted that a diverse range of plant biomass will be needed to satisfy the projected demands for advanced biofuels (Fargione et al., 2008), covering different types of lignocellulosic materials. Apart from biofuels, industrial bioproducts, chemicals, and materials that can be produced from the decomposition of biomass, play a key role in the so-called "biorefinery concept" for fostering a new bioindustry (Paster et al., 2003; Cherubini, 2010).

Forestry and agriculture residues are by nature heterogeneous in size, composition, structure, and properties (Taherzadeh and Karimi, 2008). Therefore, there are differences in the degradability of the materials (Kumar et al., 2009). Agricultural residues, such as wheat straw, have the advantage that in most cases they are easier to degrade in comparison with forest residues. This is mainly due to the lower lignin content (Kumar et al., 2009), but also due to the fact that cereals exhibit simpler cell organization with lower cell wall differentiation degree and fewer secondary structures observed (Biermann, 1997). Comparing the different types of woods, softwoods are generally more resistant to enzymatic hydrolysis compared to hardwoods, as the former contains higher lignin content (Taherzadeh and Karimi, 2008). In hardwoods and agricultural plants, xylan is the dominant hemicellulosic structure, whereas for softwoods, it is glucomannan, leading to the hypothesis that different types of biomass require a minimal set of enzymes that has to be tailormade (Banerjee et al., 2010a), i.e., more xylanases for hardwoods or more mannanases for softwoods.

For the efficient hydrolysis of different types of lignocellulosic materials, novel enzyme mixtures have to be customized. Development of these cocktails requires better knowledge about the specific activities involved, in order to optimize hydrolysis.
It would also be possible to supplement these enzyme mixtures with appropriate activities that could significantly enhance the hydrolytic potential over a range of substrates. In order to understand better the role of the individual enzymes and their synergistic interactions, the hydrolysis of wheat straw, one type of softwood (spruce) and one type of hardwood (birch) by a six component mixture at different stages was analyzed. All substrates had been pretreated to ensure an efficient enzymatic hydrolysis of cellulose by breaking down the shield formed by lignin and hemicellulose, while disrupting the crystalline structure and reducting the degree of polymerization of cellulose (Xiros et al., 2013). Different pretreatment technologies have varying effects on product yield and subsequent process steps (Wyman et al., 2005), as the overall enzyme performance is influenced by the accessibility and crystallinity of cellulose, as well as the residual lignin and hemicellulose. The enzymes used for the hydrolysis experiments were encoded by the filamentous fungus Myceliophthora thermophila (synonym Sporotrichum thermophile), a thermophilic filamentous fungus classified as an ascomycete, which constitutes an exceptionally powerful cellulolytic organism. The genome of this fungus possesses a large number of genes putatively encoding industrially important enzymes, such as carbohydrate-active enzymes, proteases, oxidoreductases, and lipases, while more than 200 sequences have been identified exclusively for plant cell-wall-degrading enzymes. These sequences encode a large number of glycoside hydrolases (GH) and polysaccharide lyases, covering the most of the recognized families (Karnaouri et al., 2014b). Most of these enzymes exhibit high thermostability. $M$. thermophila's cellulases have been shown to remain stable for temperatures up to $60^{\circ} \mathrm{C}$ (Matsakas et al., 2015a). Thermophilic enzymes would have advantages in stability during the course of harsh process conditions and increased catalytic rates at higher temperatures, potentially reducing processing times, saving energy and improving fermentation yields in downstream processes. In this study, six enzymes encoded by $M$. thermophila's genes were used to develop optimal mixtures using multicomponent optimization protocols. The results suggest that the enzymes have distinct roles that can be partially redundant in the hydrolysis of different types of lignocellulosic materials. Optimal combinations were predicted from suitable statistical models that were able to further increase hydrolysis yields, suggesting that tailor-made enzyme mixtures targeted toward a particular residual biomass can help maximize hydrolysis yields.

\section{MATERIALS AND METHODS}

\section{Substrates}

Phosphoric acid swollen cellulose (PASC) was a generous offer from Prof. Mats Sandgren, Swedish University of Agricultural Sciences, Uppsala, Sweden. Spruce and birch were provided by SLU (Umeå, Sweden). Hydrothermal pretreatment of spruce and birch took place in SEKAB E-Technology AB (Örnsköldsvik, Sweden), while wheat straw (Triticum aestivum L.) was hydrothermally pretreated in a microwave digestion equipment 
at $195^{\circ} \mathrm{C}$ for $15 \mathrm{~min}$ as previously described for the pretreatment of sweet sorghum bagasse (Matsakas and Christakopoulos, 2013). Each of forest materials was hydrothermally pretreated with sulfur dioxide as a catalyst and was received as pretreated slurries of low pH (Matsakas et al., 2015b). All slurries were filtered and washed until the $\mathrm{pH}$ reached 5.0 prior of use. Carbohydrate and lignin compositional analysis was conducted with a two-stage sulfuric acid hydrolysis treatment, according to NREL procedure (Sluiter et al., 2010). Briefly, biomass samples were hydrolyzed by $72 \%(\mathrm{w} / \mathrm{v}) \mathrm{H}_{2} \mathrm{SO}_{4}$ for $1 \mathrm{~h}$ at $30^{\circ} \mathrm{C}$, followed by dilution to $4 \%$ (w/v) $\mathrm{H}_{2} \mathrm{SO}_{4}$ and autoclave at $121^{\circ} \mathrm{C}$ for $1 \mathrm{~h}$. The acid insoluble lignin was determined gravimetrically and the sugars through HPLC equipped with and RI detector and an Aminex HPX87P column (Bio-Rad Laboratories). Ash content of the forest residues was determined with incineration of the material at $550^{\circ} \mathrm{C}$ overnight and weighing of the residues (Sluiter et al., 2012).

The crystallinity index (CrI) in the pretreated materials was determined by X-ray diffraction (XRD) using a PANalytical Empyrean X-ray diffractometer, equipped with a PixCel3D detector and a graphite monochromator. CuKÜ1 radiation with $\lambda=1.540598$ at $45 \mathrm{kV}$ and $40 \mathrm{~mA}$ was used in the $2 \theta$ range $5-90^{\circ}$ at a scanning speed of $0.026^{\circ} \mathrm{s}$. CrI was assessed with the XRD peak height method, developed by Segal and coworkers, that allows for rapid comparison between different cellulose samples. The equation used was:

$$
\mathrm{CrI}=\left(I_{002}-I_{\mathrm{AM}}\right) / \mathrm{I}_{002}
$$

where $\mathrm{I}_{002}$ and $\mathrm{I}_{A M}$ are the maximum and minimum intensity of diffraction at $\sim 2 \theta=22.4-22.6^{\circ}$ and $2 \theta=18.4-18.5^{\circ}$, respectively. $\mathrm{I}_{002}$ represents the peak intensity of the crystalline and amorphous material, and $\mathrm{I}_{\mathrm{AM}}$ represents the amorphous region only (Segal et al., 1962). Diffraction spectrum of Avicel PH-101 was used as a reference sample for crystalline cellulose.

\section{Enzymes}

With the exception of xylanase Xyl6 and GH family 26 mannanase, all individual enzymes used in these experiments were produced in high cell density cultures of Pichia pastoris, in the controlled environment of bioreactors. EG MtEG7 (GenBank ID:AEO58196.1), $\beta$-glucosidase $M t$ BGL3 (AEO58343.1), feruloyl-esterase $M t$ Fae1a (AEO62008.1), and LPMO MtGH61 (AEO56542.1) genes from $M$. thermophila were cloned and heterologously expressed in the methylotrophic yeast as previously described (Moukouli et al., 2009; Dimarogona et al., 2012; Karnaouri et al., 2013, 2014a). Genes encoding EG MtEG5 (AEO53769.1), as well as CBHs MtCBH6 (AEO55787.1) and MtCBH7 (AEO55544.1) were isolated from $M$. thermophila's genome and cloned; Escherichia coli One Shot ${ }^{\circledR}$ Top10 (Invitrogen, USA) and Zero Blunt ${ }^{\circledR}$ PCR Cloning Kit (Invitrogen, USA) were used as the host-vector system, while $P$. pastoris host strain X33 and $\mathrm{pPICZ} \alpha \mathrm{C}$ (Invitrogen, USA) were used for protein expression (unpublished data). Mannanase MtMan26a has been cloned and expressed in P. pastoris from the research group of Biotechnology laboratory, School of Chemical
Engineering, NTUA, Greece and was generously offered in purified form. Xylanase Xyl6 was a generous gift from Dyadic.

Cultivation of recombinant $P$. pastoris strains in bioreactors for the production of the enzymes was performed in the basal salts medium (BSM), supplemented by trace element solution $\mathrm{PTM}_{1}$, as described in the Pichia fermentation guidelines provided by Invitrogen (Invitrogen, Pichia Fermentation Process Guidelines). The $\mathrm{PTM}_{1}$ trace salt solution was also included in the glycerol- and methanol feeds during glycerol and methanol fed-batch phases. The only nitrogen source was ammonium hydroxide which was added as the $\mathrm{pH}$ was regulated. Cultivation started at $28^{\circ} \mathrm{C}$, aeration was set at $4 \mathrm{vvm}$ and agitation at $800 \mathrm{rpm}$. After $24 \mathrm{~h}$ of batch cultivation in glycerol medium ( $30 \mathrm{~g} / \mathrm{L}$ initial concentration), the end of glycerol batch was indicated by a sharp increase in the dissolved oxygen (DO) tension. This stage was followed by a 5-h step of fed-batch glycerol one; during this step $50 \% \mathrm{w} / \mathrm{v}$ glycerol, with $\mathrm{PTM}_{1}$ salts was fed at an initial flow rate of $12 \mathrm{~mL} / \mathrm{h} / \mathrm{L}$ of culture medium and was reduced gradually until it was fully consumed. At the same time, temperature was reduced from 28 to $25^{\circ} \mathrm{C}$ and finally to $23^{\circ} \mathrm{C}$ and $2 \mathrm{~mL}$ of methanol were added manually in small aliquots with syringe. Total consumption of glycerol was again indicated by a spike in the DO. At the onset of methanol fed-batch phase, casamino acids solution was added at a final concentration of $3 \mathrm{~g} / \mathrm{L}$ and then, a feed of $100 \% \mathrm{CH}_{3} \mathrm{OH}$, with $\mathrm{PTM}_{1}$ was initiated at a flow rate of $1.9 \mathrm{~mL} / \mathrm{h} / \mathrm{L}$. The methanol consumption rate was monitored indirectly by stopping the feed and checking the lag phase, while increasing the methanol feed rate manually. After $8 \mathrm{~h}$, feed rate was adjusted to a maximum of $5.5 \mathrm{~mL} / \mathrm{h} / \mathrm{L}$ and maintained for $\sim 20 \mathrm{~h}$, causing extracellular expression of the recombinant enzyme into the supernatant. Then, the temperature was decreased to $21^{\circ} \mathrm{C}$ and pure oxygen supply was set to maintain dissolved oxygen levels between 30 and $60 \%$. Induction time lasted $160 \mathrm{~h}$ in total and $\sim 700 \mathrm{~mL}$ of methanol were consumed.

At the end of the fermentation, the supernatants were filtrated and concentrated using a tangential flow filtration system with a $10 \mathrm{kDa}$-cutoff membrane (Pellicon XL Ultrafiltration Module Biomax $10 \mathrm{kDa}$, Millipore), buffer exchanged in dialysis tubing membrane with ten volumes of $100 \mathrm{mM}$ phosphatecitrate buffer, $\mathrm{pH}$ 5.0, and then concentrated further to $20 \mathrm{~mL}$. Concentrated desalted enzymes were rapidly purified by single-step immobilized metal ion affinity chromatography (IMAC), with a cobalt charged resin on an ÄKTA Prime Plus system, using $0-100 \mathrm{mM}$ imidazole gradient, at a flow rate of $2 \mathrm{~mL} / \mathrm{min}$. Protein concentrations were determined using the bicinchoninic acid (BCA) protein assay microplate procedure (Pierce Chemical Co., Rockford, IL), according to the manufacturer's recommendations, using bovine serum albumin as standard (Smith et al., 1985). Enzyme activities of MtEG7, $M t$ BGL3, MtFaela, and MtGH61 were assayed as described before (Moukouli et al., 2009; Dimarogona et al., 2012; Karnaouri et al., 2013, 2014a). CBH activity was tested against Avicel $5 \%(\mathrm{w} / \mathrm{v})$ in $100 \mathrm{mM}$ phosphate-citrate buffer $\mathrm{pH}=5.0$, after $24 \mathrm{~h}$ of incubation at $30^{\circ} \mathrm{C}$ and $200 \mathrm{rpm}$. Purity of the final protein preparations was determined by $12.5 \%$ SDS-PAGE electrophoresis. 


\section{Enzymatic Hydrolysis}

Hydrolysis of PASC was performed using only the four core cellulolytic enzymes ( $M t \mathrm{CBH} 7, M t \mathrm{CBH} 6, M t \mathrm{EG} 5$, and $M t \mathrm{EG} 7)$ and $\beta$-glucosidase $M t B G L 3$. In case of lignocellulosic feedstocks, the addition of accessory enzymes was based on the structure and type of each material. In all experiments, MtGH61 consisted 4\% of the enzyme mixture, while gallic acid was added at $10 \mathrm{mM}$ concentration, as electron donor. Xylanase consisted 3\% of the enzyme mixture for birch (hardwood) and 2\% for wheat straw and spruce (softwood). In case of spruce, $M t$ Man26a was added at $3 \%$ of the mixture. $M t$ Faela was used at $2 \%$ of the mixture for wheat straw and birch hydrolysis. Enzymatic reaction was performed in safe lock $2 \mathrm{~mL}$ volume microtubes. The surfactant octylphenol (ethyleneglycol)9,6 ether (Triton X-100) was added at all reactions with natural substrates at concentration $1 \mathrm{mg} / \mathrm{mL}$, which is equivalent to a surfactant addition of $4 \%$ of the substrate dry matter. Enhancement of cellulose hydrolysis by adding surfactants to the hydrolysis mixture has been reported by several authors (Helle et al., 1993; Eriksson et al., 2002a). At first, Triton X-100 and substrate were added to the hydrolysis system before any other enzyme or chemical was added, followed by preincubation at $50^{\circ} \mathrm{C}$ for $1 \mathrm{~h}$. Reactions were performed at $50^{\circ} \mathrm{C}$, with $2.5 \%$ initial dry matter content when natural substrates were used and $0.25 \%$ in case of pure substrate (PASC). The enzymes were loaded at $1 \mathrm{mg} / \mathrm{g}$ substrate for PASC and $20 \mathrm{mg} / \mathrm{g}$ substrate for lignocellulosic materials. In all reactions, $\beta$-glucosidase was added in excess in order to prevent inhibition caused by cellobiose produced by the combined action of exo- and endo$1,4-\beta$-glucanases. After $12 \mathrm{~h}$ of incubation, more $M t$ BGL3 was added, so as to ensure the effective release of glucose (Glc). All assays were replicated once, sampled twice and assayed twice for total reducing sugars (TRS) and Glc at $48 \mathrm{~h}$ of hydrolysis, for a total of four replicates of each mixture each time for each variable (TRS and Glc). TRS were measured with dinitrosalicylic acid colorimetric method (Miller, 1959) and Glc with Glucose Oxidase (GO) assay (Sigma). All reactions were performed with $1200 \mathrm{rpm}$ agitation and contained $0.02 \%(\mathrm{w} / \mathrm{v})$ sodium azide to prevent microbial contamination.

\section{Sugar Analysis and Modeling}

An experimental design was set up for the four major cellulases $M t \mathrm{CBH} 7, M t \mathrm{CBH} 6, M t \mathrm{EG} 5$, and $M t \mathrm{EG}$, so as to achieve increased saccharification, whereas accessory enzymes (MtMan26a, MtGH61, xylanases, and MtFae1a) and MtBGL3 were added at specific loadings, as mentioned above. More specifically the software Design Expert ${ }^{\circledR}$ 7.0.0 (Stat-Ease inc.) was employed where the algorithmically built $D$-optimal design was used in order to generate 20 experimental conditions (Table 1) where the four enzymes varied at specified levels (Table 2). The limits of these enzyme relative abundances were carefully chosen, in order to avoid not only working within a wide domain, as this may impact the reliability of predictions, but also limiting in a narrow domain, since extrapolation outside the borders is impossible. The lower and upper limits of each component were, therefore, determined combining data from the literature with rational considerations (Billard et al., 2012). In all the experimental combinations the summary of the enzymes was set to be equal to 1 (or $100 \%$ ), so as in all the experimental conditions the same total amount to be used and only the proportion of each enzyme to vary. The same software was used in order to evaluate the results and determine the most appropriate model that would be used to fit the experimental data. The two models applied during this work were either the quadratic (Equation 1) or the special cubic (Equation 2):

$$
\begin{gathered}
y=\sum_{j=1}^{4} b_{j} \cdot x_{j}+\sum_{1 \leq j<k \leq 4} b_{j k} \cdot x_{j} \cdot x_{k} \\
y=\sum_{j=1}^{4} b_{j} \cdot x_{j}+\sum_{1 \leq j<k \leq 4} b_{j k} \cdot x_{j} \cdot x_{k}+ \\
\sum_{1 \leq j<k<m \leq 4} b_{j k m} \cdot x_{j} \cdot x_{k} \cdot x_{m}
\end{gathered}
$$

where $y$ is the response (either TRS or Glc, $\mathrm{mg} / \mathrm{mL}$ ), $b$ are the coefficients that were estimated by the model and $x$ are the variables of the model. Optimization of the mixture was also performed by the same software, where the option to maximize either TRS or Glc was set. At the same moment the concentration of the enzymes were set to be in the limits that they were chosen to vary (Table 2). The efficiency of the model was evaluated by calculating the $p$-value and $R^{2}$. Theoretically predicted yields were verified with time-course experiments.

\section{RESULTS}

Nine different enzymes (Figure 1), all encoded by $M$. thermophila's genome, representing the main cellulolytic and hemicellulolytic activities, were used for the construction of a multi-component cocktail and were tested against one "pure" cellulosic substrate (PASC) and three hydrothermally pretreated lignocellulolytic materials (wheat straw, spruce, birch; Table 3). The X-ray diffraction spectra of pretreated substrates were examined and compared, as shown in Figure 2. The CrI for all samples was calculated from the XRD data and revealed that birch showed the highest value, followed by wheat straw and spruce (Table 4). The relative proportions of a "core" set composed of four out of the nine enzymes (two EGs and two $\mathrm{CBHs}$ ) were independently optimized for all substrates, while the accessory activities were added at specific loadings. TRS are expressed as a percentage of the total glucan content of the original feedstocks. Specific activities of the "core" enzyme set are given at Table 5. Table 6 shows the model prediction and the experimental results for TRS and Glc.

\section{Hydrolysis of PASC}

The maximum yield of sugars and Glc released from the hydrolysis of PASC was calculated using the special cubic model $\left(p=0.0002, R^{2}=0.9849\right.$ for the TRS and $p=0.0116$, $R^{2}=0.9401$ for glucose) and reached 0.69 and $0.58 \mathrm{mg} / \mathrm{mL}$, respectively. This corresponded to $24.8 \%$ hydrolysis of the substrate and was achieved with high levels of $\mathrm{MtGH}$ (40\%) 
A

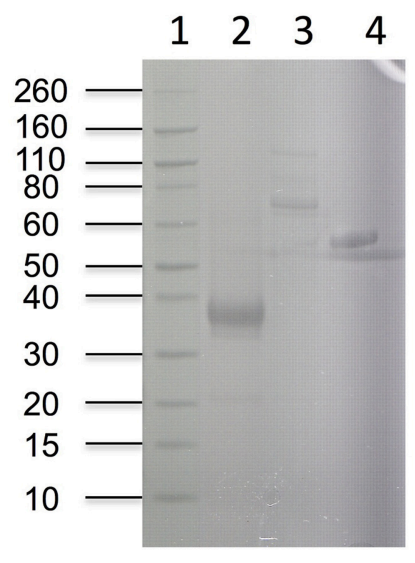

B

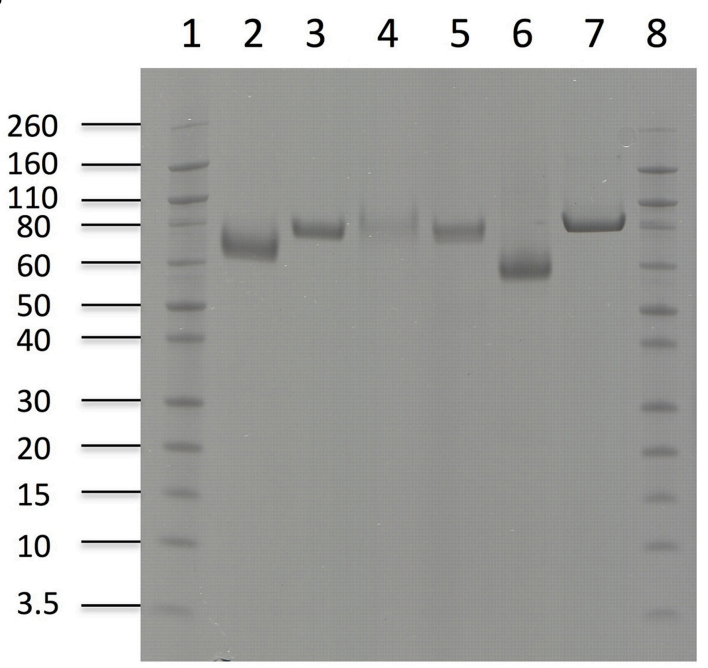

FIGURE 1 | SDS-PAGE of enzymes used in hydrolysis experiments. (A) Lanes 1: Novex ${ }^{\circledR}$ sharp pre-stained protein marker, 2: MtFae1a, 3: MtMan26a, 4: MtXyl (B) Lanes 1: Novex ${ }^{\circledR}$ sharp pre-stained protein marker, 2: MtEG7a, 3: MtEG5, 4: MtCBH7, 5: MtCBH6, 6: MtGH61, 7: MtBGL3a.

TABLE 1 | Experimental combinations used for the hydrolysis tests generated with D-optimal design (Design Expert ${ }^{\circledR}$ 7.0.0, Stat-Ease inc.).

\begin{tabular}{|c|c|c|c|c|}
\hline \multirow{2}{*}{$\begin{array}{l}\text { Number of } \\
\text { reaction }\end{array}$} & \multicolumn{4}{|c|}{ Enzyme proportions } \\
\hline & MtEG5 & MtEG7 & MtCBH6 & MtCBH7 \\
\hline 1 & 0.06 & 0.07 & 0.65 & 0.21 \\
\hline 2 & 0.20 & 0.05 & 0.53 & 0.22 \\
\hline 3 & 0.01 & 0.40 & 0.20 & 0.39 \\
\hline 4 & 0.12 & 0.33 & 0.24 & 0.31 \\
\hline 5 & 0.20 & 0.40 & 0.20 & 0.20 \\
\hline 6 & 0.01 & 0.05 & 0.47 & 0.47 \\
\hline 7 & 0.01 & 0.08 & 0.21 & 0.70 \\
\hline 8 & 0.09 & 0.19 & 0.52 & 0.20 \\
\hline 9 & 0.03 & 0.19 & 0.35 & 0.44 \\
\hline 10 & 0.01 & 0.40 & 0.20 & 0.39 \\
\hline 11 & 0.01 & 0.24 & 0.21 & 0.54 \\
\hline 12 & 0.01 & 0.05 & 0.47 & 0.47 \\
\hline 13 & 0.01 & 0.33 & 0.46 & 0.20 \\
\hline 14 & 0.20 & 0.40 & 0.20 & 0.20 \\
\hline 15 & 0.20 & 0.21 & 0.20 & 0.38 \\
\hline 16 & 0.13 & 0.05 & 0.20 & 0.62 \\
\hline 17 & 0.01 & 0.33 & 0.46 & 0.20 \\
\hline 18 & 0.06 & 0.07 & 0.65 & 0.21 \\
\hline 19 & 0.11 & 0.24 & 0.37 & 0.28 \\
\hline 20 & 0.20 & 0.05 & 0.37 & 0.38 \\
\hline
\end{tabular}

Each value represents the fraction $(\mathrm{mg} / \mathrm{mg})$ of the enzyme in the total enzyme mixture.

and MtCBH7 (27-28\%; Table 6). Experimental data using the optimal ternary mixture were close to the predicted ones $(25 \%$ hydrolysis of substrate). As illustrated in Figure 3, a decrease in $M t$ EG7 proportion results in a decrease in hydrolysis yields, even if $M t$ EG5 levels are higher, indicating the key role of GH7 EG
TABLE 2 | The respective borders for all variables used the experimental design.

\begin{tabular}{lccc}
\hline & Variable in model & Lower limit (\%) & Upper limit (\%) \\
\hline MtEG5 & $\chi_{(1)}$ & 1 & 20 \\
MtEG7 & $\chi_{(2)}$ & 5 & 40 \\
$M t C B H 6$ & $\chi_{(3)}$ & 20 & 65 \\
$M t C B H 7$ & $\chi_{(4)}$ & 2 & 70
\end{tabular}

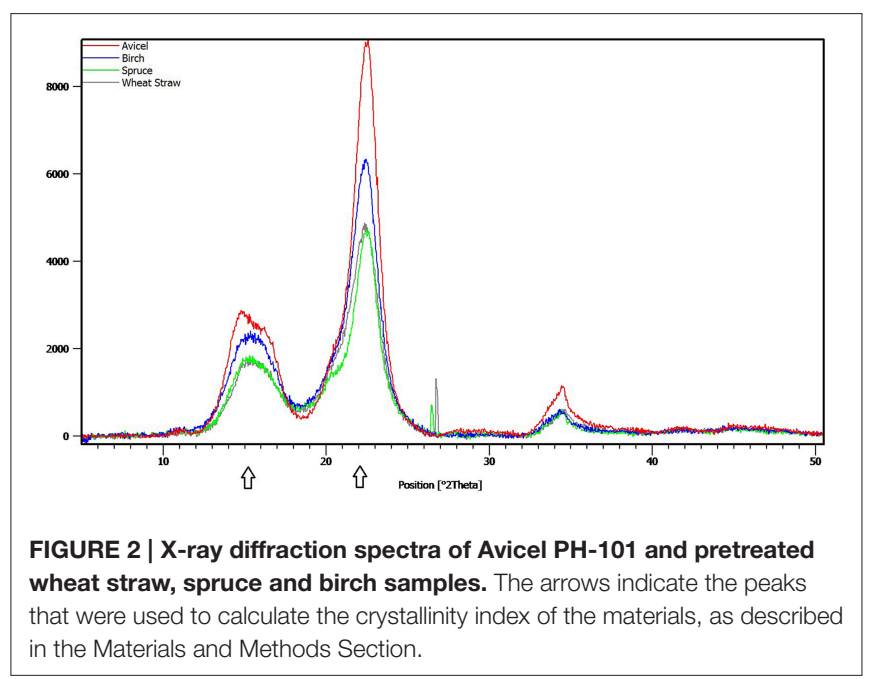

for the reaction. Even though it cannot compensate for $M t E G 7$, $M t$ EG5 is also an important enzyme; as moving toward those points (conditions, Figure 3) where $\mathrm{MtEG7}$ and $\mathrm{MtCBH7}$ are in moderate levels and MtEG5 in its lower limit proportion, the hydrolysis rate is very low. 

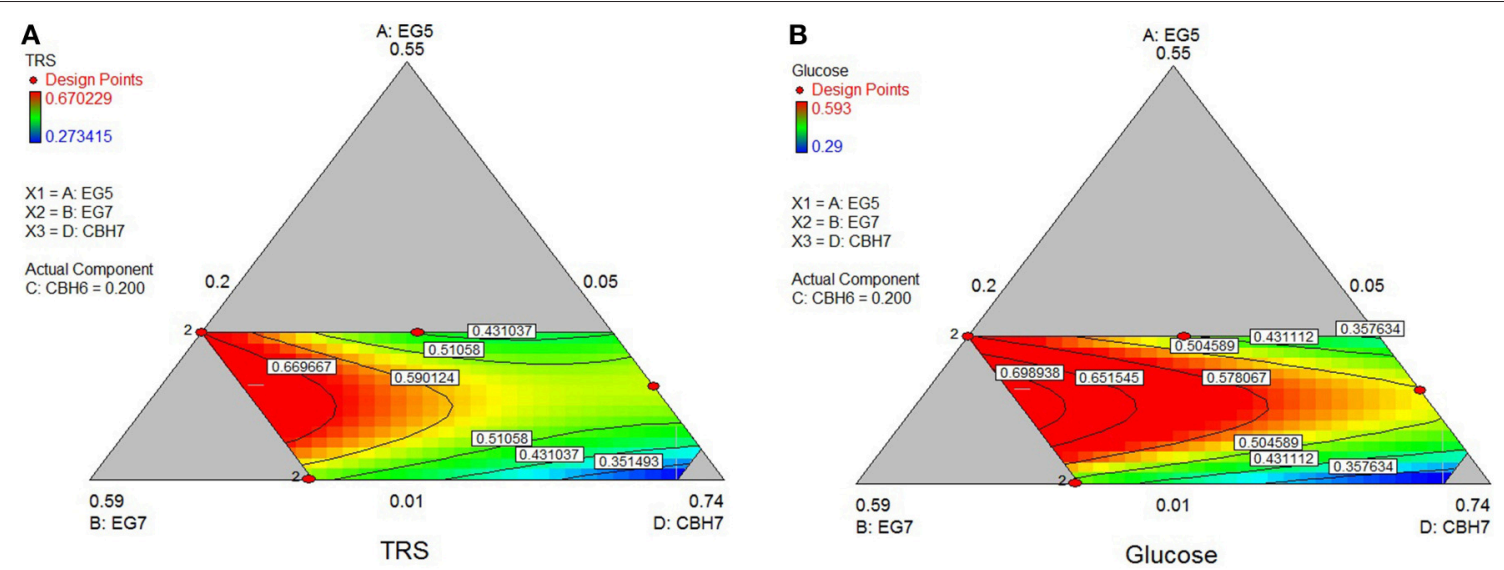

FIGURE 3 | Ternary plots showing predicted final total reducing sugars TRS (A) and GIc (B) yields from PASC hydrolysis, as a function of three out of four "core" enzymes (MtCBH7, MtEG5, MtEG7) content. For each plot, the forth enzyme (MtCBH6) has been fixed to the proportion of the point resulting in the optimal TRS yield, as predicted by the model. Ternary plots with other enzyme combinations are shown at Supplementary Material.

TABLE 3 | Compositional analysis for the pretreated materials used for hydrolysis in the present study.

\begin{tabular}{lcccc}
\hline Sample & Glucan & Xylan & Lignin & Ash \\
\hline Wheat straw & 50.2 & 3.91 & 25.5 & 2.12 \\
Spruce $^{\star}$ & 31.96 & ND & 46.69 & 0.36 \\
Birch $^{*}$ & 47.73 & 1.82 & 32.47 & 0.1 \\
\hline
\end{tabular}

ND, not detected; *Matsakas et al. (2015b).

TABLE 4 | Crystallinity index (Crl) of Avicel PH-101 and pretreated lignocellulosic samples.

\begin{tabular}{lc}
\hline Sample & Crl \\
\hline Wheat straw & 78.4 \\
Spruce & 77.3 \\
Birch & 88.2 \\
Avicel PH-101 & 96.9
\end{tabular}

The values were calculated after baseline subtraction of each spectrum.

TABLE 5 | Specific activities of purified enzymes that constitute the "core" cellulase cocktail on solid model substrates.

\begin{tabular}{lcccc}
\hline & MtCBH6 & MtCBH7 & MtEG7* & MtEG5 \\
\hline Avicel & 1.63 & 2.8 & 0.24 & 2.25 \\
CMC & 0.25 & 0.2 & 106 & 0.12
\end{tabular}

The activities are expressed in $\mu \mathrm{mol}$ of glucose equivalents released per minute permg enzyme. Substrate concentration: CMC 1\% (W/v), Avicel 5\% (w/v) for all enzymes, apart from MtEG7 that 1\% (w/v) was used. *Karnaouri et al. (2014a).

\section{Hydrolysis of Pretreated Wheat Straw}

The highest conversion of wheat straw was predicted using the quadratic model $\left(p<0.0001, R^{2}=0.9548\right.$ for total reducing sugars and $p=0.0053, R^{2}=0.8411$ for glucose) and it
TABLE 6 | Composition and final Total Reducing Sugars (TRS) and glucose (GIc) yields for optimized mixtures.

\begin{tabular}{|c|c|c|c|c|c|c|}
\hline Substrate & MtCBH7 & MtCBH6 & MtEG5 & MtEG7 & Mod. Pr. & Exp.data \\
\hline & \multicolumn{4}{|c|}{ Optimized enzyme proportions (\%) } & \multicolumn{2}{|c|}{ TRS yield $(\%)$} \\
\hline PASC & 27.2 & 20.0 & 12.8 & 40.0 & 24.7 & $25 \pm 0.7$ \\
\hline Wheat straw & 38.9 & 20.0 & 20 & 21.1 & 27.2 & $26.0 \pm 1.1$ \\
\hline Spruce & 42.2 & 20.0 & 17.8 & 20.0 & 23.6 & $27.1 \pm 0.9$ \\
\hline \multirow[t]{2}{*}{ Birch } & 24.8 & 35.6 & 20 & 19.6 & 8.8 & $7.4 \pm 0.1$ \\
\hline & \multicolumn{4}{|c|}{ Optimized enzyme proportions (\%) } & \multicolumn{2}{|c|}{ Glc yield (\%) } \\
\hline PASC & 28.2 & 20.0 & 11.8 & 40.0 & 24.2 & $24 \pm 0.9$ \\
\hline Wheat straw & 38.1 & 20.0 & 20.0 & 21.9 & 24.0 & $23.3 \pm 0.3$ \\
\hline Spruce & 32.5 & 27.6 & 12.4 & 27.5 & 21.8 & $23.1 \pm 0.8$ \\
\hline Birch & 20 & 39.1 & 20.0 & 20.9 & 6.7 & $6.9 \pm 0.2$ \\
\hline
\end{tabular}

was achieved with a ternary mixture of $38.9 \% \mathrm{MtCBH} 7+20 \%$ $M t \mathrm{CBH} 6+20 \% M t \mathrm{EG} 5+21.1 \% M t \mathrm{EG} 7$, where $27.2 \%$ of the substrate was converted. Experimental values of 48 -h hydrolysis showed a slightly decreased yield $(26.0 \pm 0.4)$ in comparison to the predicted one. The ternary plots of Figure $4 \mathrm{~A}$ show that, when the proportions of MtEG7 are increasing or decreasing over a large range, a high final yield can be conserved. Same can be noticed also for $\mathrm{MtCBH7}$. Comparing hydrolysis yields obtained with high and low $\mathrm{MtCBH} / \mathrm{MtCBH} 7$ ratio it seems that when $\mathrm{MtCBH} 7$ is in higher proportions, the yields are better. As the ratio decreases, the hydrolysis yield also follows the same tension, so $\mathrm{MtCBH} 6$ does not compensate for $\mathrm{MtCBH7}$. Even when $\mathrm{CBHs}$ participate in low proportions (lower limits), there is some hydrolysis that can be attributed to the action of MtEG7. Moving vertically toward lower MtEG7 proportions, yields are maintained, so $M t \mathrm{CBH} 7$ can compensate for $M t E G 7$ (at least partially). Similar assumptions may be made for ternary plot of Figure 4B concerning the Glc yield. 

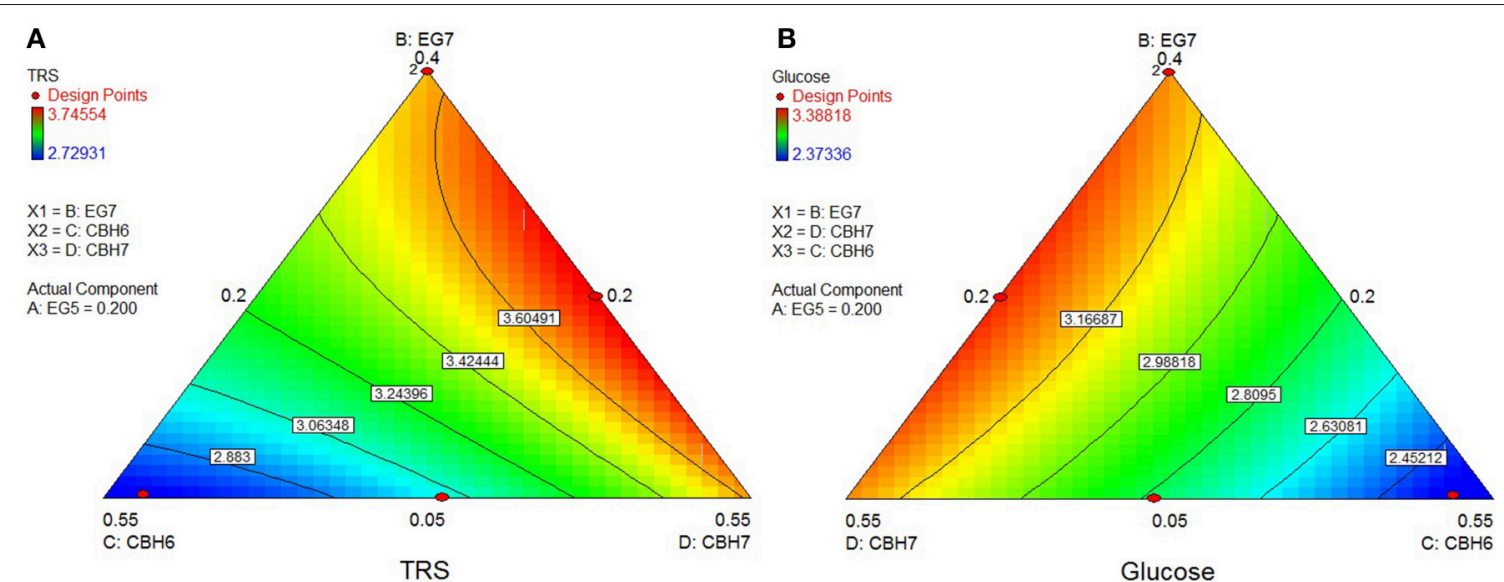

FIGURE 4 | Ternary plots showing predicted final total reducing sugars TRS (A) and GIc (B) yields from wheat straw hydrolysis, as a function of three out of four "core" enzymes (MtCBH6, MtCBH7, MtEG7) content. For each plot, the forth enzyme (MtEG5) has been fixed to the proportion of the point resulting in the optimal TRS and Glc yield, as predicted by the model. Ternary plots with other enzyme combinations are shown at Supplementary Material.

\section{Hydrolysis of Pretreated Forest Materials (Spruce, Birch)}

The optimum TRS and Glc released from spruce hydrolysis was calculated using the quadratic model $\left(p<0.0001, R^{2}=0.9463\right.$ for TRS and $p=0.0060, R^{2}=0.8364$ for glucose) and reached a hydrolysis level of $23.6 \%$. Experimental values showed an increased yield, where $27.1 \%$ of the substrate was converted within hydrolysis. This result appears to be higher than the theoretically predicted one, but close to the reaction combination \#20 that produced the highest amount of sugars (see Supplementary Material). MtCBH7 constituted $42 \%$ of the optimal enzyme mixture and, together with MtEG5, they are the key enzymes for maintaining the highest TRS yield, as highlighted by the optimal domains (Figure 5). $M t$ EG7 is also an enzyme with crucial role for the optimal Glc yield from spruce, as the optimal domain in ternary plots (Figure 5) is located where higher proportions of this enzyme are used in the enzymatic reaction mixture.

The rigid structure of birch hampered the efficient hydrolysis of its cellulolytic component, the extent of which reached only 7.4\%. Optimum TRS and Glc release was calculated using the special cubic model $\left(p<0.0001, R^{2}=0.9981\right.$ for TRS and $p=0.0008, R^{2}=0.9764$ for glucose) and achieved with a ternary mixture of $24.8 \% M t \mathrm{CBH} 7+35.6 \% \mathrm{MtCBH} 6+20 \%$ MtEG5 $+19.6 \% M t$ EG7. As shown at the ternary plots in Figure 6, the location of the optimal domain indicates that also $M t$ EG7 and MtEG5 are important for efficient hydrolysis.

\section{Time Course Hydrolysis Experiments}

The optimal enzyme combinations predicted targeting the maximum sugars yield for each material, were also tested in a time-course hydrolysis experiment. Enzyme mixtures for wheat straw, spruce and birch displayed activity of 12.01, 13.07, and 12.64 FPU/g of substrate respectively. During first $12 \mathrm{~h}$, hydrolysis rate is higher than later stage of reaction, thus leading to decreased yields and long process times (Figure 7).

\section{Accessory Enzymes and Non-ionic Surfactant Effect in Enzymatic Hydrolysis}

In order to evaluate the effect of accessory enzymes and surfactants in the performance of optimal reaction mixtures for each lignocellulosic material, differential conditions hydrolysis experiments were conducted, as illustrated in Figure 8. Supplementation of the enzyme mixture with 4\% MtGH61 resulted in 5-6\% increase of Glc yield. The greater boosting effect of LPMO was observed on the wheat straw followed by hardwood and softwood. There was no significant boosting effect when gallic or ascorbic acid was used as an exogenous synthetic reducing agent. Addition of Triton-X-100 resulted in 17\% increase of wheat straw and $5-7 \%$ of spruce and birch overall biomass saccharification. When the reaction was supplemented with accessory enzymes (xylanase, mannanase in case of spruce and feruloyl esterase in case of birch and wheat straw), the yields increased by $9 \%$ for wheat straw, $13 \%$ for spruce, and $8 \%$ for birch. The overall increase of hydrolysis levels, attributed to the whole of the additional components ( $M t \mathrm{GH} 61$, surfactant and accessory enzymes) reached 38\% for wheat straw, 28\% for spruce, and $32 \%$ for birch, referring to the amount of Glc released.

\section{DISCUSSION}

The performance of a cellulolytic cocktail against a model cellulosic substrate, such as Avicel or PASC is completely different from the one against natural lignocellulosic materials (Kabel et al., 2006; Berlin et al., 2007). In this study, the hydrolysis yields reached $25 \%$ against PASC when loaded at $1 \mathrm{mg} / \mathrm{g}$ of substrate, while in case of lignocellulosic substrates $20 \mathrm{mg} / \mathrm{g}$ of substrate were used to achieve $26 \%$ conversion of sugars in wheat straw, $27 \%$ in spruce, and $7.4 \%$ in birch. PASC is considered to be a representative of amorphous cellulose, with the macromolecular structure of cellulose as a moiety of fibers maintained (Zhang et al., 2006). In literature, optimization experiments of cellulase 

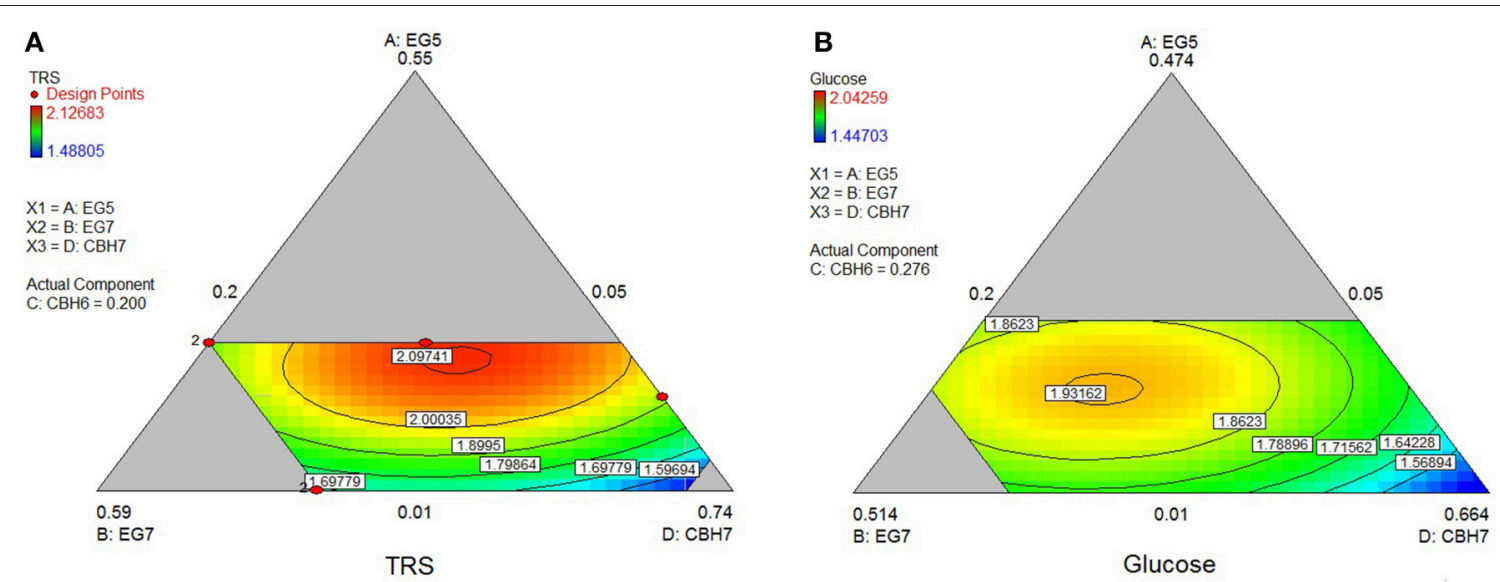

FIGURE 5 | Ternary plots showing predicted final total reducing sugars TRS (A) and Glc (B) yields from spruce hydrolysis, as a function of three out of four "core" enzymes (MtCBH7, MtEG5, MtEG7) content. For each plot, the forth enzyme (MtCBH6) has been fixed to the proportion of the point resulting in the optimal TRS yield, as predicted by the model. Ternary plots with other enzyme combinations are shown at Supplementary Material.

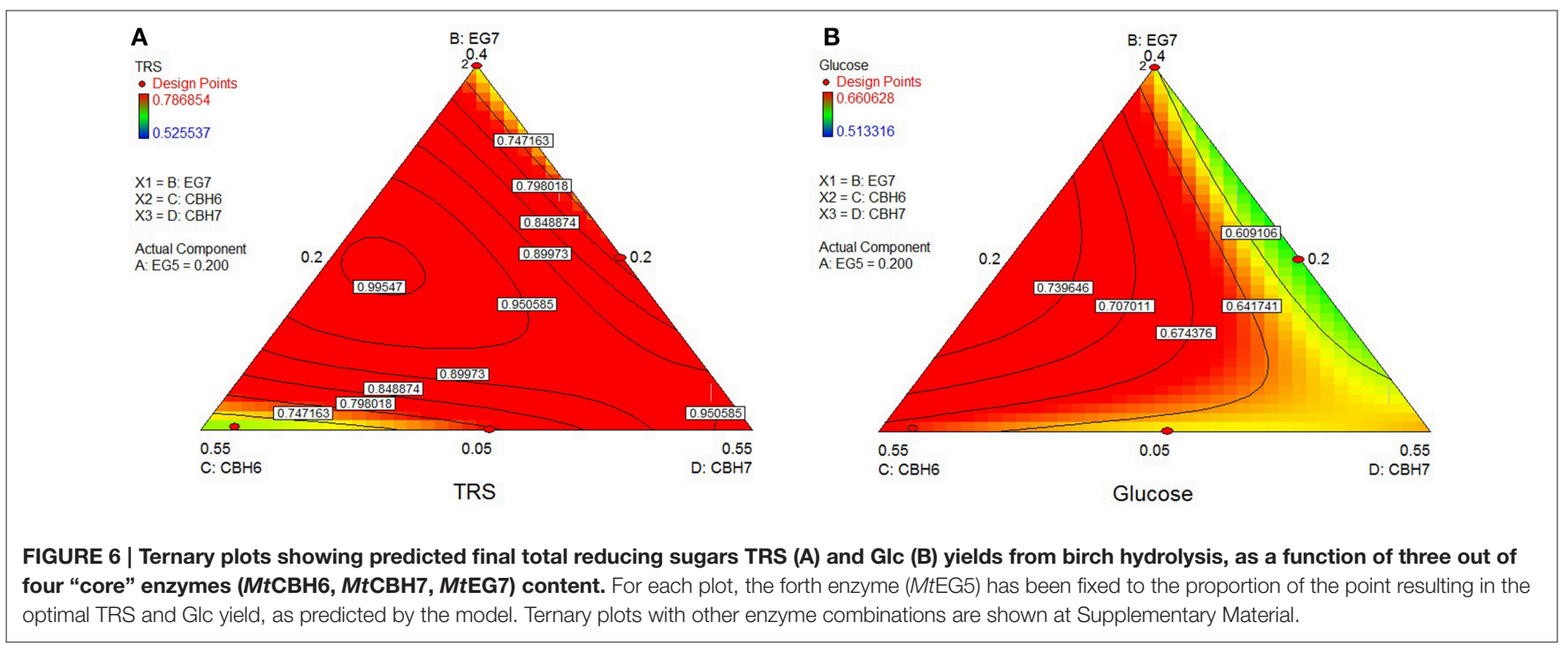

expression levels for efficient cellulose degradation have shown that high levels of EG expression are important for efficient hydrolytic activity of culture supernatant against amorphous cellulose such as PASC (Yamada et al., 2010) and it has been suggested that these substrates could almost be total degraded into Glc only by EG and BGL activity (Den Haan et al., 2007). EG5 acts as a processive enzyme by not only cleaving cellulose internally and also releasing soluble oligosaccharides from chain ends before detaching from the polysaccharide. Therefore, its activity results in alteration of the surface properties of the fibrils, while $M t E G 7$ mode of action enables digestion exclusively within the bulk of the amorphous cellulose. CBHs display synergy with EGs (Andersen et al., 2008), acting against small microcrystalline substructures, present within the relatively amorphous bulk of PASC.

In case of wheat straw hydrolysis, $\mathrm{CBH}$ hold a key role for high sugar yields. So far, CBHs are known to be important for cellulose hydrolysis (Teeri, 1997). In addition, literature data have shown that higher $\mathrm{CBH} 7 / \mathrm{CBH} 6$ ratios are more beneficial for hydrolysis of steam-exploded wheat straw than lower ones (Rosgaard et al., 2007). EGs are also of major importance for the efficient hydrolysis of pretreated wheat straw, catalyzing the initial attack on the amorphous regions of cellulose chains and the gradual reduction of the average chain length of these polysaccharides. Billard et al. (2012) showed that the optimum yield is conserved over a range from about 13 to $23 \%$ EG7. Szijarto et al. (2011) identified EG2 (Cel5a) as a key component for the liquefaction of pretreated wheat straw, while MtEG7 has also been proved to liquefy efficiently high-consistency lignocellulosic biomass by decreasing significantly the viscosity of the slurry in the first stage of reaction, underlining the crucial role of this enzyme for hydrolysis (Karnaouri et al., 2014a). The crucial role of these enzymes is highlighted in the results of the present study. Synergistic interactions between CBH I 


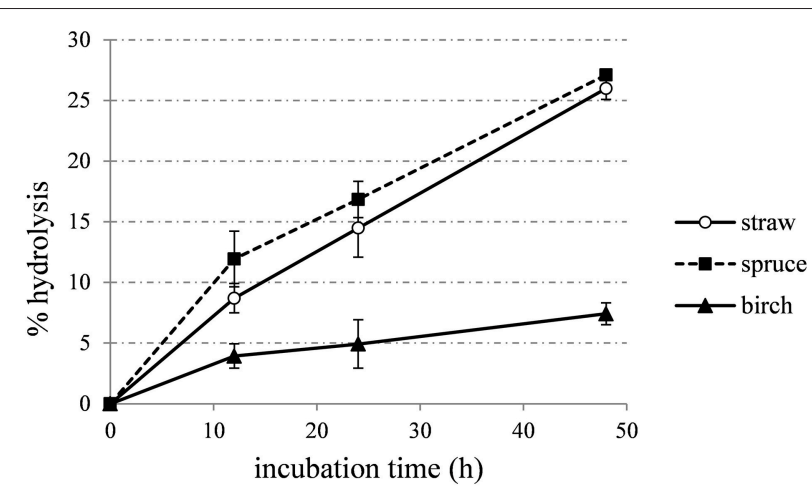

FIGURE 7 | Time course hydrolysis of wheat straw, spruce, and birch, using the enzyme combinations that were predicted to lead to the highest TRS production.

and EG have also been proven to hold a key role in hydrolysis of steam pretreated spruce, mainly caused by EG facilitating the processive hydrolytic movement of CBH I (Eriksson et al., 2002b). Regarding birch hydrolysis, CBHs consist the main component of the reaction mixture producing the highest yields, with $\mathrm{MtCBH} 7$ as the dominant factor. CBHs may be inhibited by xylan and xylan-fragments produced during the hydrolysis. Birch is a hardwood with its main hemicellulolytic component to be glucuronoxylan, so the addition of efficient proportion of xylanolytic enzymes is of great importance to maintain an optimal yield and eliminate the inhibitory effect that hampers the activity of CBHs. In this study, xylanase was used at a low proportion of $3 \%$. Inhibition state is also illustrated at Figure 7, where the hydrolysis rate drops rapidly after first $12 \mathrm{~h}$ of incubation.

Time course hydrolysis experiments against the different substrates showed that the hydrolysis rate is higher during the first $12 \mathrm{~h}$ of incubation, but seems to decrease in later stages due to the recalcitrance of the substrates. The forest materials display a more rigid structure and higher lignin content than agricultural like wheat straw, so they usually are more resistant toward deconstruction. Along the axial axes, monocots (such as wheat straw) have a different cell distribution than that observed in dicotyledonous angiosperms and gymnosperms. Even after pretreatment, which traditionally targets to disruption of microfibril structure, reduction of $\mathrm{CrI}$ and removal of hemicellulose/lignin fractions, remaining cellulosic, and non-cellulosic components exert significant restraints on hydrolysis. Cellulose contains crystalline and amorphous regions, and crystallinity is one of the most important measurable properties of cellulose affecting its enzymatic digestibility (Lee et al., 1983; Mittal et al., 2011). Amorphous or completely disordered cellulose is hydrolyzed at a much faster rate than partially crystalline cellulose (Fan et al., 1980; Hall et al., 2010), thus rendering the degree of crystallinity an important factor for the determination of the enzymatic digestibility of a cellulose sample. In this study, the CrI of the pretreated substrates was evaluated with the XRD peak height method, one of the most widely used methods for the determination of CrI, due to its ease of use. This method produces higher values than the other methods reported in the literature, but can be used as a "time-saving empirical measure of relative crystallinity" (Park et al., 2010). The relatively higher CrI value of birch substrate implied that there was a relatively higher proportion of crystalline cellulose in the samples in comparison to wheat straw and spruce and may explain differences in performance of cellulases and observed hydrolysis rates. Pretreatment severity factor value was 4.08 for spruce, 3.35 for birch, and 3.94 for wheat straw (Matsakas and Christakopoulos, 2013; Matsakas et al., 2015b), thus revealing that pretreatment conditions were more harsh for spruce than for birch, giving a possible explanation for the different values of CrI. The pretreatment of birch had little effect on cellulose crystallinity, partially reasoning for the low hydrolysis yields. Other substrate properties, such as the degree of polymerization, paracrystalline regions, the available surface area, and the pore size have to be taken into consideration. Enzyme accessibility is affected by crystallinity but also by cellulose anatomy and the lignin and hemicellulose content/distribution. These components restrict the access of cellulolytic enzymes; as a result, enzyme mixtures with similar cellulose activity may show differences in performance on different lignocellulosic materials (Berlin et al., 2006a,b).

The addition of surfactants increases hydrolysis yields and the rate of enzymatic hydrolysis, leading to reduced cellulase dosage for the hydrolysis of lignocellulosic biomasses (Borjesson et al., 2007; Kumar and Wyman, 2009; Yang et al., 2011). Different explanations to the surfactant effect on cellulose hydrolysis have been proposed until now, including the effect surfactants could have on enzyme-substrate interactions, limiting the nonproductive adsorption of enzymes on the substrate, as well as their ability to stabilize the surface tension in a solution, thus increasing enzyme stability and prevent denaturation of enzymes during hydrolysis (Eriksson et al., 2002a; Yang et al., 2011; Feng et al., 2013; Okino et al., 2013). Triton X-100 that was used as an additive to the hydrolysis experiments described in this study is a non-ionic surfactant that has a hydrophilic polyethylene oxide chain an aromatic hydrocarbon group. Although, together with Tween, Triton surfactants have showed the best improvements of lignocellulose conversion, they are not suitable for large-scale use because of the environmental effects due to the presence of the aromatic ring in the surfactant. Biosurfactants, surface-active substances synthesized by living cells, are becoming more and more popular for their high efficiency and virulence (Feng et al., 2013).

Accessory enzymes (LPMOs, xylanases, and feruloylesterases) can all significantly enhance the hydrolytic performance of cellulase enzyme mixtures. The recently discovered family of AA9 LPMOs includes metallo-enzymes that cleave cellulose chain by an oxidative mechanism with the reaction taking place at the protein's active site through a divalent metal ion, a type II copper, and, uniquely, a methylated histidine in the copper's coordination sphere (Quinlan et al., 2011; Aachmann et al., 2012; Li et al., 2012). For efficient performance of these enzymes, a reductant/redox-active cofactor that works as an external electron donor is needed (Forsberg et al., 2011). 

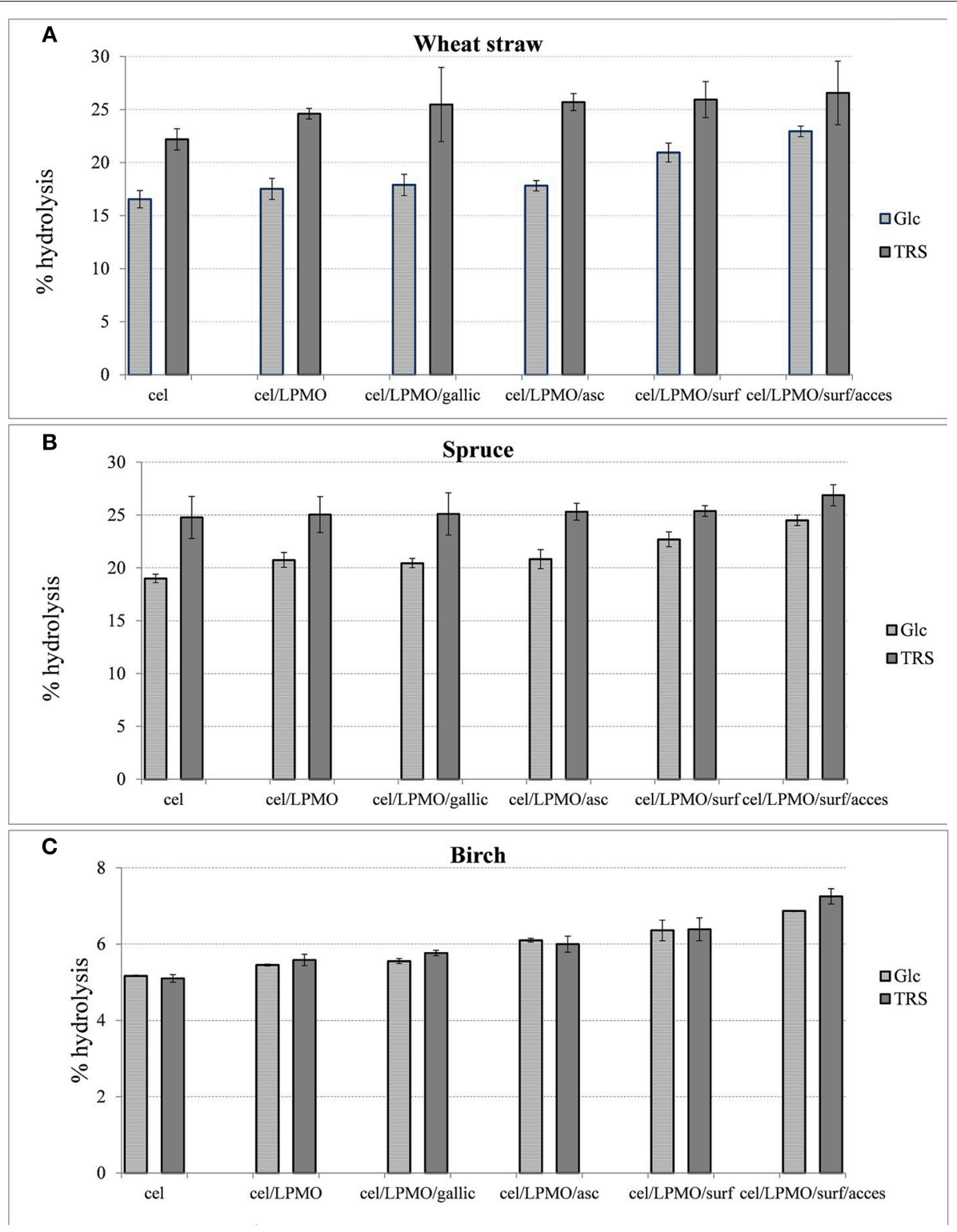

FIGURE 8 | The percentage increase after $48 \mathrm{~h}$ hydrolysis, with cellulases (MtEG7, MtEG5, MtCBH6, MtCBH7, MtBGL3), of steam pretreated wheat straw (A), spruce (B), and birch (C) after the addition of MtGH61, reducing agents (gallic acid, ascorbic acid), surfactant (Triton X-100), and accessory enzymes (wheat straw: Xyl6, MtFae1a, MtMan26a, spruce: Xyl6, MtMan26a, birch: Xyl6, MtFae1a).

Cannella et al. (2012) showed that under commercially relevant conditions, around $4.1 \%$ of the glycosidic bonds in cellulose were oxidatively cleaved by presumably LPMO enzymes. In this study, the addition of $M t \mathrm{GH} 61$ resulted in a significant increase of Glc yield; however, to detect the total extent of enhancement, determination of oxidative products should also be conducted. It has been demonstrated that non-cellulosic material present in the pretreated substrates, such as lignin and hemicellulose, is able to act as a cofactor providing reductant residues for the LPMO activity, so as no additional reducing agent is required (Dimarogona et al., 2012; Hu et al., 2014; Westereng et al., 2015). The synergistic interaction of xylanase with cellulases during hydrolysis of the cellulosic component of biomass has been demonstrated in earlier studies using corn stover (Alvira et al., 2011; Qing and Wyman, 2011). The observed xylanase-boosting effect is attributed to the removal of hemicellulose that has remained associated with the cellulosic-rich water insoluble fraction after pretreatment (Chandra et al., 2007). Xylanases have also been shown to result in the solubilization of lignin fractions from pretreated lignocellulosic biomass by breaking down the lignin-carbohydrate complex and consequently improving substrate digestibility (deJong et al., 1997; Suurnakki et al., 1997). In a way similar to EGs, they affect the viscosity of the reaction mixture and facilitate the substrate liquefaction by either 
increasing the free water in the hydrolysis system or reducing particle size of the pretreated biomass (Viamajala et al., 2009; Di Risio et al., 2011). Hu et al. (2015) has shown that replacing some of the cellulase mixture with an equivalent amount of xylanase leads to increased hydrolysis of the pretreated corn stover substrate substantially, by about $30 \%$ and poplar by $8 \%$. In the present study, it was apparent that xylanase treatment could significantly improve the cellulose hydrolysis of all of the lignocellulosic substrates assessed, even for the steam pretreated softwood that contained virtually no xylan. Moreover, it has been suggested that xylanases, apart from the cleavage of hemicellulolytic bonds, they also interact with cellulases by altering gross fiber characteristics, like fiber swelling and fiber porosity. In that way, cellulose accessibility is increased and hydrolysis yields rise (Hu et al., 2011). In a similar way, LPMOs and carbohydrate-binding modules, CBMs have been suggested to promote the amorphogenesis of substrates, thus enhancing the effectiveness of cellulase enzymes (Arantes and Saddler, 2011). A synergistic effect between cellulases, FAEs and xylanases for the hydrolysis of wheat straw has been proven (Tabka et al., 2006; Selig et al., 2008). Ferulic acid is the most abundant hydroxy cinnamic acid in the cell wall (Mueller-Harvey and Hartley, 1986) and is covalently cross-linked to monocot and hardwood arabinoxylans by ester bonds and to components of lignin mainly by ether bonds (Akin et al., 1996). The lignin monomers, monolignols, also with help of ferulic acid, cross-link between each other and with hemicelluloses and increase the density of the cell wall. In case of pretreated spruce, where lignin reaches $47 \%$ of the total biomass, incorporation of feruloyl-esterase in the enzyme mixture is imperative. Accessory enzymes such as feruloyl esterases should also act in synergy with xylanases by cleaving diferulic bridges between xylan chains, opening the structures, releasing lignin and increase the accessibility of cellulases to the substrate (Faulds and Williamson, 1995; Yu et al., 2002).

Hydrolysis ratios of this tailor-made enzyme cocktail can be improved with the addition of other enzyme components. It was shown in the literature that xylanases from different families (10 and 11) act synergistically leading to increase of Glc yields (Banerjee et al., 2010a,b; Gao et al., 2011; Zhang et al., 2011). In our experiments we used one xylanase from $M$. thermophila, at concentration of $2-3 \%$ of the total enzyme loading. The required amount of accessory enzymes and the extent of their synergistic cooperation with cellulases has been shown to be highly substrate, dependent during hydrolysis of pretreated lignocellulosic substrates ( $\mathrm{Hu}$ et al., 2015). Though the addition of enzymes with xylanolytic activity would lead only to minor improvements on steam-exploded wheat straw, as this substrate contains only very little xylan, it can be hypothesized that an additional xylanase (as well as $\beta$-xylosidase) would raise the release of reducing sugars from birch (xylan is the dominant hemicelluloses component) and other forest materials.

\section{CONCLUSION}

The efficient hydrolysis of pretreated lignocellulosic substrates requires a consortium of enzymes mainly comprised of high levels of cellulases, together with lower amounts of enzymes that attack non-cellulosic components, such as lignin and hemicellulose. Attempts to improve the performance of such enzyme complexes have mainly focused on cellulases because cellulose is the dominant component in lignocellulose, as well as the main source of glucose for the production of energy, chemicals and materials. As a first step toward evaluating this approach for improving the enzymatic cocktails, the increase of the enzymatic hydrolysis of different agricultural and forest residues, such as wheat straw, softwoods (spruce), and hardwoods (birch) was investigated. These substrates show significant quantitative and qualitative differences in their noncellulosic polysaccharide components. A statistical model was set up to search for optimized enzymatic mixtures containing four core enzymes, in the presence of other five "accessory" enzymes, all encoded by $M$. thermophila's genes. The present results suggest that $\mathrm{MtCBH7}$ and $M t \mathrm{EG7}$ are enzymes of major importance for optimized final reducing sugars and glucose yields during the hydrolysis of pretreated wheat straw, while $M t \mathrm{CBH} 7$ plays a crucial role in case of spruce. $\mathrm{CBHs} M t \mathrm{CBH} 6$ and $M t \mathrm{CBH} 7$ act in combination and are key enzymes for the hydrolysis of the hardwood (birch). For the hydrolysis of the pure substrate (PASC), high proportions of endoglucanases, especially MtEG7 are needed for efficient yields.

\section{AUTHOR CONTRIBUTIONS}

AK produced the enzymes, carried out the hydrolysis experiments and wrote the manuscript. LM set up the experimental design and developed the statistical models. ET contributed in the molecular cloning and heterologous expression of the enzymes. UR and PC participated in study conception, data interpretation and corrected the manuscript. All authors have read and approved the final manuscript.

\section{ACKNOWLEDGMENTS}

AK thanks the State Scholarships Foundation (Greece) for a Fellowship for a Short Term Scientific Mission to Luleå University of Technology. LM, UR, and PC thank Bio4Energy, a strategic research environment appointed by the Swedish government, for supporting this work.

\section{SUPPLEMENTARY MATERIAL}

The Supplementary Material for this article can be found online at: http://journal.frontiersin.org/article/10.3389/fmicb. 2016.00177 


\section{REFERENCES}

Aachmann, F. L., Sørlie, M., Skjåk-Bræk, G., Eijsink, V. G., and Vaaje-Kolstad, G. (2012). NMR structure of a lytic polysaccharide monooxygenase provides insight into copper binding, protein dynamics, and substrate interactions. Proc. Natl. Acad. Sci. U.S.A. 109, 18779-18784. doi: 10.1073/pnas.1208 822109

Akin, D. E., Morrison, W. H., Rigsby, L. L., Gamble, G. R., Sethuraman, A., and Eriksson, K.-E. L. (1996). Biological delignification pf plant components by the white rot fungi Ceriporiopsis subvermispora and Cyathus stercoreus. Anim. Feed Sci. Tech. 63, 305-321. doi: 10.1016/S0377-8401(96) 00998-4

Alvira, P., Tomas-Pejo, E., Negro, M. J., and Ballesteros, M. (2011). Strategies of xylanase supplementation for an efficient saccharification and cofermentation process from pretreated wheat straw. Biotechnol. Progr. 27, 944-950. doi: $10.1002 /$ btpr.623

Andersen, N., Johansen, K. S., Michelsen, M., Stenby, E. H., Krogh, K. B. R. M., and Olsson, L. (2008). Hydrolysis of cellulose using mono - component enzymes shows synergy during hydrolysis of phosphoric acid swollen cellulose (PASC), but competition on Avicel. Enzyme Microb. Technol. 42, 362-370. doi: 10.1016/j.enzmictec.2007.11.018

Arantes, V., and Saddler, J. N. (2011). Cellulose accessibility limits the effectiveness of minimum cellulase loading on the efficient hydrolysis of pretreated lignocellulosic substrates. Biotechnol. Biofuels. 4:3. doi: 10.1186/1754-68 34-4-3

Banerjee, G., Car, S., Scott-Craig, J. S., Borrusch, M. S., Bongers, M., and Walton, J. D. (2010a). Synthetic multi-component enzyme mixtures for deconstruction of lignocellulosic biomass. Bioresour. Technol. 101, 9097-9105. doi: 10.1016/j.biortech.2010.07.028

Banerjee, G., Car, S., Scott-Craig, J. S., Borrusch, M. S., and Walton, J. D. (2010b). Rapid optimization of enzyme mixtures for deconstruction of diverse pretreatment/biomass feedstock combinations. Biotechnol. Biofuels 3:22. doi: 10.1186/1754-6834-3-22

Berlin, A., Balakshin, M., Gilkes, N., Kadla, J., Maximenko, V., Kubo, S., et al. (2006a). Inhibition of cellulase, xylanase and beta-glucosidase activities by softwood lignin preparations. J. Biotechnol. 125, 198-209. doi: 10.1016/j.jbiotec.2006.02.021

Berlin, A., Gilkes, N., Kilburn, D., Maximenko, V., Bura, R., Markov, A., et al. (2006b). Evaluation of cellulase preparations for hydrolysis of hardwood substrates. Appl. Biochem. Biotechnol. 129-132, 528-545. doi: 10.1385/ABAB:130:1:528

Berlin, A., Maximenko, V., Gilkes, N., and Saddler, J. (2007). Optimization of enzyme mixtures for lignocellulose hydrolysis. Biotechnol. Bioeng. 97, 287-296. doi: 10.1002/bit.21238

Bhat, M. K. (2000). Cellulases and related enzymes in biotechnology. Biotechnol. Adv. 18, 355-383. doi: 10.1016/S0734-9750(00)00041-0

Biermann, C. J. (ed.). (1997). "Wood and fiber - growth and anatomy," in Handbook of Pulping and Papermaking, 2nd Edn (San Diego, CA: Elsevier Inc.), 516-540.

Billard, H., Faraj, A., Lopes-Ferreira, N., Menir, S., and Heiss-Blanquet, S. (2012). Optimization of a synthetic mixture composed of major Trichoderma reesei enzymes for the hydrolysis of steam-exploded wheat straw. Biotechnol. Biofuels 5:9. doi: 10.1186/1754-6834-5-9

Borjesson, J., Engqvist, M., Sipos, B., and Tjerneld, F. (2007). Effect of poly(ethylene glycol) on enzymatic hydrolysis and adsorption of cellulase enzymes to pretreated lignocellulose. Enzyme Microb. Technol. 41, 186-195. doi: $10.1016 /$ j.enzmictec.2007.01.003

Cannella, D., Hsief, C. C., Felby, C., and Jorgensen, H. (2012). Production and effects of aldonic acids during enzymatic hydrolysis of lignocelluloses at high dry matter content. Biotechnol. Biofuels 5:26. doi: 10.1186/17546834-5-26

Chandra, R. P., Bura, R., Mabee, W. E., Berlin, A., Pan, X., and Saddler, J. N. (2007). Substrate pretreatment: the key to effective enzymatic hydrolysis of lignocellulosics. Biofuels 108, 67-93. doi: 10.1007/10_2007_064

Cherubini, F. (2010). The biorefinery concept: using biomass instead of oil for producing energy and chemicals. Energ. Convers. Manage. 51, 1412-1421. doi: 10.1016/j.enconman.2010.01.015
deJong, E., Wong, K. K. Y., and Saddler, J. N. (1997). The mechanism of xylanase prebleaching of kraft pulp: an examination using model pulps prepared by depositing lignin and xylan on cellulose fibers. Holzforschung 51, 19-26. doi: 10.1515/hfsg.1997.51.1.19

Den Haan, R. S., Rose, H., Lynd, L. R., and van Zyl, W. H. (2007). Hydrolysis and fermentation of amorphous cellulose by recombinant Saccharomyces cerevisiae. Metab. Eng. 9, 87-94. doi: 10.1016/j.ymben.2006. 08.005

Dimarogona, M., Topakas, E., Olsson, L., and Christakopoulos, P. (2012). Lignin boosts the cellulase performance of a GH-61 enzyme from Sporotrichum thermophile. Bioresour. Technol. 110, 480-487. doi: 10.1016/j.biortech.2012.01.116

Di Risio, S., Hu, C. S., Saville, B. A., Liao, D., and Lortie, J. (2011). Large-scale, highsolids enzymatic hydrolysis of steam-exploded poplar. Biofuel Bioprod. Bior. 5 , 609-620. doi: 10.1002/bbb.323

Eriksson, T., Borjesson, J., and Tjerneld, F. (2002a). Mechanism of surfactant effect in enzymatic hydrolysis of lignocellulose. Enzyme Microb. Technol. 31, 353-364. doi: 10.1016/S0141-0229(02)00134-5

Eriksson, T., Karlsson, J., and Tjerneld, F. (2002b). A model explaining declining rate in hydrolysis of lignocellulose substrates with cellobiohydrolase I (Cel7A) and endoglucanase I (Cel7B) of Trichoderma reesei. Appl. Biochem. Biotechnol. 101, 41-60. doi: 10.1385/ABAB:101:1:41

Fan, L. T., Lee, Y. H., and Beardmore, D. H. (1980). Mechanism of the enzymatic hydrolysis of cellulose: effect of major structural features of cellulose on enzymatic hydrolysis. Biotechnol. Bioeng. 23, 177-199. doi: 10.1002/bit.260220113

Fargione, J., Hill, J., Tilman, D., Polasky, S., and Hawthorne, P. (2008). Land clearing and the biofuel carbon debt. Science 319, 1235-1238. doi: $10.1126 /$ science. 1152747

Faulds, C. B., and Williamson, G. (1995). Release of ferulic acid from wheat bran by a ferulic acid esterase (FAE-III) from Aspergillus niger. Appl. Microbiol. Biotechnol. 43, 1082-1087. doi: 10.1007/BF00 166929

Feng, Y., Jiang, J., Zhu, L., Yue, L., Zhang, J., and Han, S. (2013). Effects of tea saponin on glucan conversion and bonding behaviour of cellulolytic enzymes during enzymatic hydrolysis of corncob residue with high lignin content. Biotechnol. Biofuels 6:161. doi: 10.1186/17546834-6-161

Forsberg, Z., Vaaje-Kolstad, G., Westereng, B., Bunaes, A. C., Stenstrom, Y., MacKenzie, A., et al. (2011). Cleavage of cellulose by CBM33 protein. Protein Sci. 20, 1479-1483. doi: 10.1002/pro.689

Gao, D. H., Uppugundla, N., Chundawat, S. P. S., Yu, X. R., Hermanson, S., Gowda, K., et al. (2011). Hemicellulases and auxiliary enzymes for improved conversion of lignocellulosic biomass to monosaccharides. Biotechnol. Biofuels 4:5. doi: $10.1186 / 1754-6834-4-5$

Hall, M., Bansal, P., Lee, J. H., Realff, M. J., and Bommarius, A. S. (2010). Cellulose crystallinity - a key predictor of the enzymatic hydrolysis rate. FEBS J. 277, 1571-1582. doi: 10.1111/j.1742-4658.2010.07585.x

Helle, S. S., Duff, S. J. B., and Cooper, D. G. (1993). Effect of surfactants on cellulose hydrolysis. Biotechnol. Bioeng. 42, 611-617. doi: 10.1002/bit.260420509

Horn, S. J., Vaaje-Kolstad, G., Westereng, B., and Eijsink, V. G. (2012). Novel enzymes for the degradation of cellulose. Biotechnol. Biofuels 5:45. doi: $10.1186 / 1754-6834-5-45$

Hu, J., Arantes, V., Pribowo, A., Gourlay, K., and Saddler, J. (2014). Substrate factors that influence the synergistic interaction of AA9 and cellulases during the enzymatic hydrolysis of biomass. Energy Environ. Sci. 7, 2308-2315. doi: $10.1039 / \mathrm{c} 4 \mathrm{ee} 00891 \mathrm{j}$

Hu, J., Arantes, V., and Saddler, J. N. (2011). The enhancement of enzymatic hydrolysis of lignocellulosic substrates by the addition of accessory enzymes such as xylanase: is it an additive or synergistic effect? Biotechnol. Biofuels 4:36. doi: $10.1186 / 1754-6834-4-36$

Hu, J., Chandra, R., Arantes, V., Gourlay, K., van Dyk, J. S., and Saddler, J. N. (2015). The addition of accessory enzymes enhances the hydrolytic performance of cellulase enzymes at high solid loadings. Bioresour. Technol. 186, 149-153. doi: 10.1016/j.biortech.2015.03.055

Kabel, M. A., van der Maarel, M. J., Klip, G., Voragen, A. G., and Schols, H. A. (2006). Standard assays do not predict the efficiency of commercial 
cellulase preparations towards plant materials. Biotechnol. Bioeng. 93, 56-63. doi: 10.1002/bit.20685

Karnaouri, A., Topakas, E., Antonopoulou, I., and Christakopoulos, P. (2014b). Genomic insights into the fungal lignocellulolytic system of Myceliophthora thermophila. Front. Microbiol. 5:281. doi: 10.3389/fmicb.2014.00281

Karnaouri, A., Topakas, E., Paschos, T., Taouki, I., and Christakopoulos, P. (2013). Cloning, expression and characterization of an ethanol tolerant GH3 $\beta$-glucosidase from Myceliophthora thermophila. PeerJ 1:e46. doi: 10.7717/peerj.46

Karnaouri, A. C., Topakas, E., and Christakopoulos, P. (2014a). Cloning, expression, and characterization of a thermostable GH7 endoglucanase from Myceliophthora thermophila capable of high-consistency enzymatic liquefaction. Appl. Microbiol. Biotechnol. 98, 231-242. doi: 10.1007/s00253-0134895-9

Kumar, P., Barrett, D. M., Delwiche, M. J., and Stroeve, P. (2009). Methods for pretreatment of lignocellulosic biomass for efficient hydrolysis and biofuel production. Ind. Eng. Chem. Res. 48, 3713-3729. doi: 10.1021/ie801542g

Kumar, R., and Wyman, C. E. (2009). Effect of additives on the digestibility of corn stover solids following pretreatment by leading technologies. Biotechnol. Bioeng. 102, 1544-1557. doi: 10.1002/bit.22203

Lee, S. B., Kim, I. H., Ryu, D. D. Y., and Taguchi, H. (1983). Structural properties of cellulose and cellulase reaction mechanism. Biotechnol. Bioeng. 25, 33-51. doi: 10.1002/bit.260250105

Li, X., Beeson, W. T., Phillips, C. M., Marletta, M. A., and Cate, J. H. (2012). Structural basis for substrate targeting and catalysis by fungal polysaccharide monooxygenases. Structure 20, 1051-1061. doi: 10.1016/j.str.2012. 04.002

Matsakas, L., Antonopoulou, I., and Paul Christakopoulos, P. (2015a). Evaluation of Myceliopthora thermophila as an enzyme factory for the production of thermophilic cellulolytic enzymes. Bioresources 10, 5140-5158. doi: 10.15376/biores.10.3.5140-5158

Matsakas, L., and Christakopoulos, P. (2013). Fermentation of liquefacted hydrothermally pretreated sweet sorghum bagasse to ethanol at highsolids content. Bioresour. Technol. 127, 202-208. doi: 10.1016/j.biortech.2012. 09.107

Matsakas, L., Rova, U., and Christakopoulos, P. (2015b). Sequential parametric optimization of methane production from different sources of forest raw material. Front. Microbiol. 6:1163. doi: 10.3389/fmicb.2015.01163

Miller, G. L. (1959). Use of dinitrosalicylic acid reagent for determination of reducing sugars. Anal. Chem. 31, 426-428. doi: 10.1021/ac60147a030

Mittal, A., Katahira, R., Himmel, M., and Johnson, D. (2011). Effects of alkaline or liquid-ammonia treatment on crystalline cellulose: changes in crystalline structure and effects on enzymatic digestibility. Biotechnol. Biofuels 4:41. doi: 10.1186/1754-6834-4-41

Moukouli, M., Topakas, E., and Christakopoulos, P. (2009). Molecular characterization and bioinformatics analysis of the feruloyl esterase system of Fusarium oxysporum. N. Biotechnol. 25, 131-132. doi: 10.1016/j.nbt.2009.06.442

Mueller-Harvey, I., and Hartley, R. D. (1986). Linkage of p-coumaroyl and feruloyl groups to cell-wall polysaccharides of barley straw. Carbohydr. Res. 148, 71-85. doi: 10.1016/0008-6215(86)80038-6

Okino, S., Ikeo, M., Ueno, Y., and Taneda, D. (2013). Effects of Tween 80 on cellulase stability under agitated conditions. Bioresour. Technol. 142, 535-539. doi: 10.1016/j.biortech.2013.05.078

Park, S., Baker, J. O., Himmel, M. E., Parilla, P. A., and Johnson, D. K. (2010). Cellulose crystallinity index: measurement techniques and their impact on interpreting cellulase performance. Biotechnol. Biofuels. 3:10. doi: 10.1186/1754-6834-3-10

Paster, M., Pellegrino, J. L., and Tracy, M. C. (2003). Industrial Bioproducts: Today and Tomorrow, Energetics Inc., Columbia, Maryland for the U.S. Washington, DC: Department of Energy, Office of Energy Efficiency and Renewable Energy, Office of the Biomass Program.

Qing, Q., and Wyman, C. E. (2011). Supplementation with xylanase and beta-xylosidase to reduce xylo-oligomer and xylan inhibition of enzymatic hydrolysis of cellulose and pretreated corn stover. Biotechnol. Biofuels 4:18. doi: 10.1186/1754-6834-4-18

Quinlan, R. J., Sweeney, M. D., Lo Leggio, L., Otten, H., Poulsen, J. C., Johansen, K. S., et al. (2011). Insights into the oxidative degradation of cellulose by a copper metalloenzyme that exploits biomass components. Proc. Natl. Acad. Sci. U.S.A. 108, 15079-15084. doi: 10.1073/pnas.1105776108

Rosgaard, L., Pedersen, S., Langston, J., Akerhielm, D., Cherry, J. R., and Meyer, A. S. (2007). Evaluation of minimal Trichoderma reesei cellulase mixtures on differently pretreated barley straw substrates. Biotechnol. Prog. 23, 1270-1276. doi: 10.1021/bp070329p

Segal, L., Creely, J. J., Martin, A. E. Jr., and Conrad, C. M. (1962). An empirical method for estimating the degree of crystallinity of native cellulose using the x-ray diffractometer. Tex. Res. J. 29, 786-794.

Selig, M. J., Knoshaug, E. P., Adney, W. S., Himmel, M. E., and Decker, S. R. (2008). Synergistic enhancement of cellobiohydrolase performance on pretreated corn stover by addition of xylanase and esterase activities. Bioresour. Technol. 99, 4997-5005. doi: 10.1016/j.biortech.2007.09.064

Sluiter, A., Hames, B., Ruiz, R., Scarlata, C., Sluiter, J., Templeton, D., et al. (2012). Determination of Structural Carbohydrates and Lignin in Biomass. Technical Report, National Renewable Energy Laboratory, NREL/TP-510-42618.

Sluiter, J. B., Ruiz, R. O., Scarlata, C. J., Sluiter, A. D., and Templeton, D. W. (2010). Compositional analysis of lignocellulosic feedstocks 1: review and description of methods. J. Agric. Food Chem. 58, 9043-9053. doi: 10.1021/jf1008023

Smith, P. K., Krohn, R. I., Hermanson, G. T., Mallia, A. K., Gartner, F. H., Provenzano, M. D., et al. (1985). Measurement of protein using bicinchoninic acid. Anal. Biochem. 150, 76-85. doi: 10.1016/0003-2697(85)90442-7

Sun, Y., and Cheng, J. (2002). Hydrolysis of lignocellulosic materials for ethanol production: a review. Bioresour. Technol. 83, 1-11. doi: 10.1016/S09608524(01)00212-7

Suurnakki, A., Li, T. Q., Buchert, J., Tenkanen, M., Viikari, L., Vuorinen, T., et al. (1997). Effects of enzymatic removal of xylan and glucomannan on the pore size distribution of kraft fibres. Holzforschung 51, 27-33. doi: 10.1515/hfsg.1997.51.1.27

Szijarto, N., Siika-aho, M., Sontag-Strohm, T., and Viikari, L. (2011). Liquefaction of hydrothermally pretreated wheat straw at high-solids content by purified Trichoderma enzymes. Bioresour. Technol. 102, 1968-1974. doi: 10.1016/j.biortech.2010.09.012

Tabka, M. G., Herpoel-Gimbert, I., Monod, F., Asther, M., and Sigoillot, J. C. (2006). Enzymatic saccharification of wheat straw for bioethanol production by a combined cellulase xylanase and feruloyl esterase treatment. Enzyme Microb. Technol. 39, 897-902. doi: 10.1016/j.enzmictec.2006.01.021

Taherzadeh, M. J., and Karimi, K. (2008). Pretreatment of lignocellulosic wastes to improve ethanol and biogas production: a review. Int. J. Mol. Sci. 9, 1621-1651. doi: 10.3390/ijms9091621

Teeri, T. T. (1997). Crystalline cellulose degradation: new insight into the function of cellobiohydrolases. Trends Biotechnol. 15, 160-167. doi: 10.1016/S01677799(97)01032-9

Viamajala, S., McMillan, J. D., Schell, D. J., and Elander, R. T. (2009). Rheology of corn stover slurries at high solids concentrations - Effects of saccharification and particle size. Bioresour. Technol. 100, 925-934. doi: 10.1016/j.biortech.2008.06.070

Westereng, B., Cannella, D., Wittrup Agger, J., Jørgensen, H., Larsen Andersen, M., Eijsink, V., et al. (2015). Enzymatic cellulose oxidation is linked to lignin by long-range electron transfer. Sci. Rep. 21:18561. doi: 10.1038/srep18561

Wyman, C. E., Dale, B. E., Elander, R. T., Holtzapple, M., Ladisch, M. R., and Lee, Y. Y. (2005). Comparative sugar recovery data from laboratory scale application of leading pretreatment technologies to corn stover. Bioresour. Technol. 96, 2026-2032. doi: 10.1016/j.biortech.2005.01.018

Xiros, C., Topakas, E., and Christakopoulos, P. (2013). Hydrolysis and fermentation for cellulosic ethanol production. WIREs Energy Environ. 2, 633-654. doi: 10.1002/wene.49

Yamada, R., Taniguchi, N., Tanaka, T., Ogino, C., Fukuda, H., and Kondo, A. (2010). Cocktail delta-integration: a novel method to construct cellulolytic enzyme expression ratio-optimized yeast strains. Microb. Cell Fact. 9:32. doi: 10.1186/1475-2859-9-32

Yang, M., Zhang, A., Liu, B., Li, W., and Xing, J. (2011). Improvement of cellulose conversion caused by the protection of Tween- 80 on the adsorbed cellulase. Biochem. Eng. J. 56, 125-129. doi: 10.1016/j.bej.2011.04.009

Yu, P., Maenz, D. D., McKinnon, J. J., Racz, V. J., and Christensen, D. A. (2002). Release of ferulic acid from oat hulls by Aspergillus ferulic acid esterase and Trichoderma xylanase. J. Agric. Food Chem. 50, 1625-1630. doi: $10.1021 /$ jf010984r 
Zhang, J., Tuomainen, P., Siika-aho, M., and Viikari, L. (2011). Comparison of the synergistic action of two thermostable xylanases from GH families 10 and 11 with thermostable cellulases in lignocellulose hydrolysis. Bioresour. Technol. 102, 9090-9095. doi: 10.1016/j.biortech.2011.06.085

Zhang, M., Su, R., Qi, W., and He, Z. (2010). Enhanced enzymatic hydrolysis of lignocellulose by optimizing enzyme complexes. Appl. Biochem. Biotechnol. 160, 1407-1414. doi: 10.1007/s12010-009-8602-3

Zhang, Y. H., Cui, J., Lynd, L. R., and Kuang, L. R. (2006). A transition from cellulose swelling to cellulose dissolution by o-phosphoric acid: evidence from enzymatic hydrolysis and supramolecular structure. Biomacromolecules 7, 644-648. doi: 10.1021/bm050799c
Conflict of Interest Statement: The authors declare that the research was conducted in the absence of any commercial or financial relationships that could be construed as a potential conflict of interest.

Copyright (c) 2016 Karnaouri, Matsakas, Topakas, Rova and Christakopoulos. This is an open-access article distributed under the terms of the Creative Commons Attribution License (CC BY). The use, distribution or reproduction in other forums is permitted, provided the original author(s) or licensor are credited and that the original publication in this journal is cited, in accordance with accepted academic practice. No use, distribution or reproduction is permitted which does not comply with these terms. 